\title{
LOVE IN THE NATURE OF HAPPINESS: EXISTING-HUMANISTIC ASPECT
}

In Happiness And Contemporary Society : Conference Proceedings Volume (Lviv, March, 20-21, 2021). Lviv: SPOLOM, 2021. P. 140-144. https://doi.org/10.31108/7.2021.31

ISBN 978-966-919-697-2

\section{ЛЮБОВ У ПРИРОДІ ЩАСТЯ: ЕКЗИСТАНЦЙНО-ГУМАНІСТИЧНИЙ АCПЕКТ}

// Щастя та сучасне суспільство : збірник матеріалів міжнародної наукової конференції (Львів, 20-21 березня 2021 р.). - Львів : СПОЛОМ, 2021. С. 140-144. https://doi.org/10.31108/7.2021.31

ISBN 978-966-919-697-2 


\section{HURLYEVA Tetyana}

$P h D$ in Psychology, Senior Researcher, G.S.Kostiuk Institut eof Psychology of NAES of Ukraine (Kyiv, Ukraine)

\section{LOVE IN THE NATURE OF HAPPINESS: EXISTING-HUMANISTIC ASPECT}

Ще великі філософи, такі, The article emphasizes the importance of humane values in personal development, in the fullest, creative realization of a person's human essence, in the continuous pursuit of happiness. It is the proclamation and implementation of such values as goodness, justice, compassion, responsibility, freedom, conscience, dignity, honor, and others. From the standpoint of the existential-humanistic approach, the role of love as a value in the nature of happiness, its connection with creativity, spirituality, and dreams is considered. Love as one of the most important human values, the high meaning of life, the spiritual ability of man can be manifested in various types of relationships. The author of the article focuses on love for all that exists - for other people, for nature, for life, for the world, on the meaning of a person's ability to give and receive love.

Key words: happiness, love, dream, creativity, meaning of life, spirituality, existential-humanistic aspect

ГУРЛСВА Тетяна

кандидат психологічних наук, старший науковий співробітник Інститут психологї імені Г.С.Костюка НАПН Украӥни (м. Київ, Україна)

\section{ЛЮБОВ У ПРИРОДІ ЩАСТЯ: ЕКЗИСТАНЦЙНО-ГУМАНІСТИЧНИЙ АСПЕКТ}

Щастя - у сериі, серие - улюбові, любов - у законі Вічного (Григорій Сковорода)

Людина повноцінно живе і вдосконалюється, коли прагне щось важливе i справжнє вчинити у своєму житті, шукає шляхи для кращої самореалізації, втілюючи смисл життя. У широкому розумінні смисл - це цінність і водночас переживання цієї цінності в процесі ii становлення та реалізації. Смисл народжується, відкривається, усвідомлюється і постійно змінюється (М. Бахтін, С. Братченко, Ф. Василюк, А. Ленгле, Д. Леонтьєв, В. Франкл та ін.).

Вчені наголошують на тому, що необхідним $є$ гармонійне поєднання соціального, біологічного і духовного в розвитку і саморозвитку особистості (О. Бодальов, С. Максименко, С. Рубінштейн, В. Чудновський та ін.). Не кожен смисл або система смислів веде до вдосконалення особистості. Має значення, які саме смисли наснажують людину, визначають іiі поведінку і впливають на іï життєвий шлях, відчуття щастя. Від того, які саме цінності стануть провідними, домінуючими, охоплюючими увесь життєвий простір людини, вирішальним чином залежить становлення іï особистості. Сучасна психологія визнає можливість гармонійного існування людини лише за наявності у неї найвищого, сутнісного, буттєвого смислу життя. Як зазначав психолог В. Чудновський, життєві смисли не існують самі по собі, а підпорядковані найважливішому, найвищому смислу, який 
забезпечує високу якість життя людини, стає «цінністю надзвичайно високого порядку» $[7$, с. 5$]$.

Психологічна наука апелює до гуманних цінностей, що сприяє більш повному i вільному проживанню, яскравому переживанню, усвідомленню, осмисленню людиною свого життя, відкриттю для себе високих смислів. Це допомагає особистісному розвитку, творчій реалізації людиною своєї людської сутності, забезпечує неперервне прямування до щастя. Це проголошення і втілення таких цінностей як добро, справедливість, співчуття, любов, творчість, відповідальність, свобода, совість, гідність, честь та ін.

Людина не може бути гармонійною істотою, якщо позбавлена справжнього життя і глибини, не здатна створювати прекрасне, творити себе і змінювати світ на краще. У цій статті ми торкнемося такого дивовижного явища як любов, іiі особливостей i ознак прояву. Про любов, розкриваючи іiі екзистенційногуманістичну роль в бутті людини, писали у своїх працях такі філософи, психологи, письменники, як М. Бердяєв, О. Бодальов, М. Боришевський, С. К'єркегор, С. Максименко, Г.Марсель, Ж.-П.Сартр, Сократ, В. Соловйов, В. Татенко та багато інших. На сьогоднішній день ця тема залишається актуальною для наукових пошуків вчених всього світу.

Адже людина стає людиною у любові і тільки через неї. Як справедливо зазначає Т. Кучера, любов - необхідна складова умова людського щастя, одна 3 найважливіших людських цінностей, духовна здатність людини, що може проявлятися у різноманітних видах стосунків. «Природа любові - у такому єднанні, - пише філософіня, - яке не пригнічує, а розкриває внутрішні можливості особистості. Любов — це фундаментальна потреба, цінність людини, від якої залежить ії повноцінний розвиток, реалізація особистісного та творчого потенціалу, найбільш адекватна людині, особистості форма екзистенції. Завдяки їй кожен відчуває повноту, змістовність, гармонійність життя та причетність усьому сущому. Поза любов'ю неможлива ні адекватна самореалізація особистості, ні ефективна взаємодія з навколишнім середовищем» [3, с. 74-75].

Любов - це особлива форма творчості, високе мистецтво, що вимагає постійного саморозвитку, самовдосконалення, самозречення, готовності до вчинку, це мелодія, яка не може бути фальшивою, а відображає найтонші і найщиріші поштовхи живої душі. Любов треба невпинно пізнавати і розкривати, досліджуючи усю гаму і повноту емоцій і почуттів, навіть протилежних і взаємозаперечуючих, заглиблюватись у іï цілющі невичерпні джерела та знов і знов оновлюватись та вдосконалюватись. Навіть зазнаючи поразок i страждань, людина прагне переосмислювати їх і перетворювати на здатність любити, силу любові. Адже людина, зазначає Л. Сморж, «як біосоціальна істота функціонує цілісно, і ця цілісність вимагає як позитивних, так і негативних емоцій, переживань, станів як вираження порушення гармонії і необхідності іï відновлення, збалансованості свого організму і психіки. Людина має часом неусвідомлену потребу не тільки в насолодах, комфорті, влаштованості, безпеці, в емоціях радості, любові, захоплення, полегшення, але й у потрясіннях і небезпеках, випробовувати себе на міцність, мужність, витривалість, життєздатність, що примушує іiі підкоряти гірські вершини, стрибати 3 парашутом, долати власними силами океан тощо» $[5$, c. 274].

Секретом і вершиною сили любові є здатність не брати, а віддавати, а ще точніше - дарувати (бо поєднання слів «дати - брати» може мати й корисливу 
основу, означати очікування подяки), що дивним чином сприяє збагаченню того, кого люблять, бо він обов'язково отримує, відчуває свою цінність через іншого, через його кохання, переживає щастя. «Віддаючи, - пише Е. Фромм, - я відчуваю власну силу, багатство, владу. Відчуття зрослої життєвої сили і могутності наповнює мене радістю. Давати радісніше, ніж отримувати, але не тому, що я втрачаю щось, а тому, що в цьому акті проявляється моя життєва сила» [6, с. 9698]. Вагомою ознакою справжньої любові бачиться також здатність їі приймати. У люблячого $€$ надзвичайна властивість помічати найменші порухи любові у іншого, і ці знаки вона сприймає як безцінний Дар за своє кохання, як відповідь на своє почуття. Тому й отримує те, у чому будь-хто інший не узрів би й найменшого натяку на любов, увагу, повагу, а ще й ніжність, яка, на думку філософа М. Бердяєва, є тією якістю, яка складає самий центр любовних стосунків [1]. А щиро приймати, це значить так само віддавати у відповідь.

Безумовно, любов - найцілюща і найпрекрасніша, бодай не найєдиніша, подія в житті людини, і у кожного неповторна. Вона допомагає повірити в себе справжнього, а ще пізнавати іншу людину в ії глибинній сутності, розгледіти в ній «промінчик Господній», високе творіння 3 найкращими рисами, піднесеними мріями, сподіваннями, задумами. Той, хто любить, здатен «бачити» здатності і потенції об'єкта своєї любові, таким, яким він «може стати і бути», у кращих своїх проявах. Не дивно, що у коханому ми помічаємо те, чого інші не бачать, і не втомлюємося дивуватися i захоплюватися: «Який він добрий, гарний, найкращий!». Справжня любов об'єднує люблячих, але водночас зберігає цілісність кожної окремої особистості, не руйнуючи їі самобутності й незмірності. Причому, писав Конфуцій: «Велике щастя - це коли тебе люблять, справжнє щастя - це коли любиш ти».

Важливою властивістю любові є повнота існування у єдності зі значущими іншими, протилежністю якої виступає почуття покинутості, самотність, страх спілкування, нелюбов. Е. Фромм витлумачує любов як творче, життєстверджуюче ставлення людини до людини, як силу, яка долає перепони у стосунках і власному розвитку. «Любов - це активна сила, яка руйнує стіни, що відділяють людину від інших людей, і об'єднує іiі 3 ними; любов допомагає подолати почуття ізольованості та самотності і в той же час залишитися самою собою, зберегти власну цілісність». Любов - сила, що допомагає долати одинокість і безнадію, натомість несучи іншому радощі, щастя, натхнення, що розподіляються i множаться на двох.

Тільки у любові людина здатна по-справжньому відчути смисл свого земного існування як існування для іншого. Це - спорідненість душ, яка неодмінно доповнює і збагачує власне існування. Це - звучання в унісон, співзвучність, у результаті якої, вважав М. Пришвін, і виникає любов [4]. Безумовну любов i прихильність він назвав «сутнісними стосунками», а те, що поєднує людей «сутнісними зв'язками». Батьки, рідні місця, батьківський дім сприймаються людьми «як свої», рідні, невід'ємні від власного життя. В основі цих сутнісних стосунків лежить закладена від природи потреба в прихильності, приналежності, любові. Безумовність між чоловіком і жінкою зустрічається не так часто, для цього мають бути досить значущі речі, важливі сторони життя, які б їх об'єднували. Але що має бути обов'язково - то це взаємність і рівнозначність, без чого неможлива повна, справжня розділеність. На думку письменника, любов чоловіка і жінки $\epsilon$ найсуттєвішим зв'язком зі світом. 
Сутнісні зв'язки - це незбагненні золоті ниточки, тонкі і легкі, але їх не можна ні розірвати, ні розрубати, ані будь-яким іншим чином знищити. Та вони можуть розчинитися, щезнути від нелюбові, зради, брехні. Сутнісні зв'язки істинні, тому й непорушні, і тому найдорожчі. За таке почуття закохані ладні ризикнути i власним життям. Згадаймо В. Висоцького: «...Они уже согласны заплатить. Любой ценой - и жизнью бы рискнули, Чтобы не дать порвать, чтоб сохранить Волшебную невидимую нить, Которую меж ними протянули...». Любов дозволяє людині повною мірою розкрити свою індивідуальність, знайти свою сутнісну цілісність у єднанні з коханою людиною, стати більш досконалим. Тому розділена любов $\epsilon$ справжнім щастям, вона сприяє найповнішому, найціліснішому, найгармонійнішому самовияву людини, стає умовою подальшого розвитку i розквіту обох особистостей. Може тому людина виявляє непереборний потяг подолати свою одинокість, прагнення реалізувати свою потребу у коханні.

Втім, для того, щоб зустріти своє кохання, зауважує Е. Фромм, слід бути до цього хоча б трохи підготовленим. Адже любов - це не птаха щастя, яка сідає на плечі, і важливо іiї не сполохати. Це почуття, яке вимагає певної особистісної зрілості і розуміння тієї відповідальності, яка необхідна для зближення зі своєю другою половинкою, вимагає такої особистої свободи і любові до себе, сущого в собі, щоб щиро полюбити іншого, дати йому любов і свободу. Це закономірний плід зусиль і знань, адже важливо не стільки бути коханим, скільки навчитися $\mathrm{i}$ вміти любити самому. Любити - то віддавати, піклуватися, поважати, бути відповідальним, це активна зацікавленість у житті і розвитку того, кого ми любимо, здатність бачити іншу людину такою, якою вона $\epsilon$, усвідомлювати іiі унікальну індивідуальність, яка постійно змінюється і розвивається. Повага i відповідальність були б сліпі, якби їх не направляло знання, яке $є$ інструментом пізнання таїни людини, зазначає Е. Фромм.

Можна говорити про різні види любові: братська, материнська, еротична, любов до себе і любов до Бога. Братська любов можлива між рівними, коли людину не можна використовувати в будь-яких корисливих цілях. Така любов, як i любов-дружба, торкається стосунків близьких один одному людей, вона являє «душевний спокій», внутрішнє єднання, взаєморозуміння. Материнська любов виявляє прив'язаність батьків до своєї дитини - малесенької беззахисної істоті, а далі - людини, що потребує підтримки, піклування, знань, досвіду. Для сексуального і еротичного почуття використовується термін «еротична любов» як злиття в фізичному і в духовному сенсі. На жаль, часто молоді люди фізичний контакт сприймають як відчуття психологічної близькості, що є ілюзією єдності. «Статевий потяг, - пише Е. Фромм, -...без любові... залишає людей такими ж чужими один одному, якими вони були раніше...» [6]. Це робить людину ще самотнішою і викликає тяжкі переживання, робить ії нещасливою.

Любов, на думку Е. Фромма, є «риса особистості, яка має бути обов'язково присутньою не лише у відношеннях до своєї родини і друзів, а також до тих, з ким людина вступає в контакт на роботі, у справах, у своїй професійній діяльності». Любов - це форма ставлення до світу в цілому. Тому варто говорити про любов до всього сущого, природи, будь-яких живих істот, про важливість бути відкритим до стосунків і отримувати любов ззовні. Між людиною і будь-чим живим встановлюється, вважав М. Пришвін, «родинний зв'язок»: «Щоб з будь-яким створінням, мишеням, ялинкою, зайцем, встановити цей родинний зв'язок, треба ж усього себе зі всім цілим світом привести у зв'язок. I попереджав, що всяка любов 
$€$ зв'язок, та не всякий зв'язок $є$ любов, що справжня любов - $є$ моральна творчість, духовний злет. У своїх Щоденниках він пише, що сутність любові полягає в очікуванні. Нехай навіть усе життя. Щоб самому бути щасливим, переповненим цим почуттям, і дарувати любов іншим.

I ще. Щастя пов'язують зі мрією, яка втілюється, реалізується в житті і породжує нові мрії. Щасливою може бути «дорога до щастя» - як радісне, солодке очікування невідворотньої омріяної миті чи події (наприклад, зустрічі $з$ коханою людиною). Або так зване «можливе щастя», що є найбільним скарбом, за М. Пришвіним. Але не будь-яке зреалізоване дарує відчуття щастя, духовного піднесення, повноти існування. Як часто ми стикаємося зі фразою «Я мрію бути щасливим!». Б. Паскаль писав: «Справжнє щастя дає тільки мрія про майбутнє щастя». Але що це може означати? Японці кажуть: «Не вчи Долю поганому. Мрійте про хороше». В.-М. Гюго говорив: «Живі борються... А живі лише ті, Чиє серце віддане піднесеній мрії». А ще він писав: «Найбільше схожі на нас наші фантазії. Кожному мрія малюється відповідно його натурі». Це суголосно думці Г. Сковороди, про те, що яке серце має людина, тою вона і $є$ насправді: "Кожен $є$ той, чиє серце в нім: вовче серце - справжній вовк, хоч обличчя людське; серце боброве - бобер, хоч вигляд вовчий; серце вепрове - вепр, хоч подоба бобра" [2, с.70]. Отже мрія, фантазії, уявлення про щастя залежить від того, чим наповнене серце людини, чого вона по-справжньому прагне.

Григорій Сковорода наснажує, звертаючись до нашого серця і розуму: «Любов є джерело всього Життя. Хіба не любов все поєднує, будує, творить, подібно до того, як ворожість руйнує? Хіба не мертвою є душа, позбавлена істинної любові? Що дає основу? - Любов. Що творить? - Любов. Що зберігає? Любов, любов. Що дає насолоду? - Любов, любов, початок, середина, кінеиь, альфа і омега...». Філософ нагадує, що джерело любові - в нас самих: «Любов виникає з любові, коли хочу, щоб мене любили, я сам першим люблю».

Екзистенційно-гуманістичний аспект залишається актуальним орієнтиром у розумінні любові, яка є сутністю щастя людини, плекається у глибині іï серця $\mathrm{i}$ щиро віддається у світ.

\section{ЛІТЕРАТУРА}

4. Бердяев Н. Самопознание /Гл. 2, в кн. Эрос и личность. Философия пола и любви. М., Прометей, 1989. С. 135.

5. Власенко В.В. У світі афоризмів Григорія Сковороди. Культура народов Причерноморья. 2004. № 53. С. 70-72.

6. Кучера Т.М. Онтологічні та морально-екзистенційні виміри любові. Університетська кафедра. 2013. № 2. С. 74-89.

7. Пришвин М.М. Пришвина В. Д. Мы с тобой. Дневник любви. М.: Художественная литература, 1996.

8. Сморж Л.О. Естетика: Навчальний посібник. К.: Кондор, 2005. 334 с.

9. Фромм Э. Искусство любить. Человеческая ситуация. М.: Смысл, 1994.

10. Чудновский В.Э. Смысл жизни: проблема относительной эмансипированности от «внешнего» и «внутреннего». Психологический журнал. 1995. Т. 16. С. 15-26. 